\title{
ANTIBACTERIAL EFFECT OF TWO TYPES OF NANO PARTICLES INCORPORATED IN ZINC OXIDE BASED SEALERS ON ENTEROCOCCUS FAECALIS (IN VITRO STUDY)
}

\author{
Hala F. Mohammed ${ }^{I} B D S$, Mohammed M. Ibrahim² $P h D$, \\ Abd El-Fattah H. Abd El-Fattah ${ }^{3} P h D$, Thanaa I. Shalaby $P h D$
}

\begin{abstract}
INTRODUCTION: Antibacterial properties of nanoparticles have recently come into the spotlight in endodontic therapy.

OBJECTIVES: Evaluation of the antimicrobial efficacy of zinc oxide based sealer incorporated with silver and zinc oxide nanoparticles compared with simple zinc oxide sealer against Enterococcus faecalis.

MATERIALS AND METHODS: The study was conducted on 60 human extracted mandibular premolars. After instrumentation of all teeth and inoculation of root canals with Enterococcus faecalis, teeth were divided into three groups according to the type of the tested sealer, Group I: control group where teeth were obturated with unmodified zinc oxide based sealer. Group II: teeth were obturated using sealer modified with silver nanoparticles, Group III: teeth were obturated using sealer modified with zinc oxide nanoparticles. Each group was subdivided into two subgroups according to the timing of filling removal and culture sample. Subgroup A: filling removal and culture sample were taken after one week. Subgroup B: filling removal and culture sample were taken after three weeks. Colony counting technique was used, the number of colony forming unites method was counted to assess the effect against Enterococcus faecalis. Data were recorded, tabulated and statistically analyzed using Friedman test to compare the differences between the three groups.

RESULTS: After three weeks from obturation, silver nanoparticles had a superior antibacterial effect and there was a significant difference between the three tested groups, but after one week of obturation there was no significant difference between the three tested groups.

CONCLUSION: In three weeks samples after obturation silver nanoparticles had a superior antibacterial effect and there was a significant difference between the three tested groups, but after one week of obturation there was no significant difference between the three tested groups. KEY WORDS: Enterococcus faecalis, silver nanoparticles, zinc oxide nanoparticles, zinc oxide eugenol sealer.
\end{abstract}

1- $\quad$ Master student of Endodontic Dentistry, Department of Conservative Dentistry, Faculty of Dentistry, Alexandria University, Egypt.

2- $\quad$ Professor of Endodontics, Department of Conservative, Faculty of Dentistry, Alexandria University, Egypt.

3- Professor of Microbiology, High institute of public health, Alexandria University, Egypt.

4- Professor of Medical Biophysics, Medical Research Institute, Alexandria University, Egypt.

\section{INTRODUCTION}

Complete obturation of root canal system is one of the major objectives of endodontic treatment. To achieve this goal, combination of chemical and mechanical cleaning and shaping techniques are used. However, these procedures are one of the most important factors in success of endodontic treatment. Therefore, obturation materials including root canal sealers should have antibacterial effect by adding antimicrobial agents to these sealers.

Microorganisms and their by-products are considered to be the major cause of pulpal and periradicular pathosis. The bacteria most frequently found in infected root canals are various, it includes Enterococcus, Streptococcus, Peptostreptococcus and Actinomyces and others.

Enterococcus faecalis is a Gram positive facultative anaerobic bacterium found in the human normal flora. Enterococcus faecalis is a dominant pathogen, demonstrating resistance to various irrigates and medicaments. Enterococcus faecalis can be virulent in the complex anatomical variations of the root canal system, including accessory canals, inter-canal communications and apical ramifications.

Nanotechnology is the science of evaluating and producing materials in nano-dimensions by re-location and re-arrangement of atoms to prepare materials with better properties. Presence of very small particles leads to superior properties of the material.

Nanoparticles are being used as therapeutic tool against infectious microbes. Among noble metal nanoparticles, silver nanoparticles have received considerable attention owing to their attractive physicochemical properties.

Silver nanoparticles are attractive as these are non-toxic to human body at low concentration and having broadspectrum antibacterial nature. Silver nanoparticles inhibit the bacterial growth at very low concentration than antibiotics and as of now no side effects are reported.

Also a new experimental endodontic sealer (zinc oxide nano-powder) is used. This sealer is similar to various zinc oxide eugenol based sealers, but with different sizes of nanoparticles of zinc oxide.

The hypothesis of the present research was that zinc oxide sealer mixed with different nanoparticles has a stronger antibacterial action than zinc oxide sealer alone against Enterococcus faecalis.

This comparative study represents the antibacterial effect of silver nano particles and zinc oxide nanoparticles in comparison to zinc oxide sealer only against Enterococcus faecalis.

\section{MATERIALS AND METHODS}

For this study sixty freshly extracted human mandibular premolars with single canals extracted for periodontal or orthodontic reasons were used. The selected teeth were cleaned after extraction from tissue remenants and debris on their surfaces. Teeth were sterilized using an autoclave at $120^{\circ} \mathrm{C}$ for 20 minutes. The teeth were stored in normal sterile saline to prevent their dehydration until used. 
Access opening was performed in each tooth conventionally by using high speed round and endo-z burs under water cooling, the pulp was removed and the working length was determined by penetration of \# $15 \mathrm{~K}$-file into the canal till just appearing from the apical foramen then one $\mathrm{mm}$ was subtracted from the measurement to confirm the working length.

Root canals of all teeth were enlarged till size\# $35 \mathrm{k}$-file, irrigation was performed using normal sterile saline by a three $\mathrm{ml}$ disposable plastic syringe with a 27 gauge needle for two minutes. Root canals were then dried using sterile paper points \# 35 .

The apical three millimeters of the outer root surfaces were coated with epoxy resin and left to dry in order to seal the root canal foramina and to prevent bacterial leakage during inoculation, bio-mechanical preparation and obturation.

Each tooth was mounted vertically by friction inside a sterile eppendorf to prevent root canal contamination during procedures and to make both handling and identification easier, this was performed by making a hole through the center of each eppendorf by using low speed hand piece and each tooth was inserted under pressure up to its cementoenamel junction.

Epoxy resin was filled at the interface between the tooth and eppendorf to avoid leakage. The system was sterilized in autoclave at $120^{\circ} \mathrm{C}$ for 20 minutes to prevent any contamination with other bacteria.

\section{Preparation of the bacterial suspension}

Standard strain of Enterococcus faecalis bacteria was subcultured on blood agar plates and incubated in aerobic condition for 24 hours at $37^{\circ} \mathrm{C}(1)$.

A suspension of the bacterial colonies was prepared in sterile nutrient broth. The bacterial suspension was vortexed to obtain a homogenous suspension of bacterial solution.

The bacterial suspension was adjusted compared with 0.5 McFarland turbidity standards $\left(1.5 \times 10^{8} \mathrm{cfu} / \mathrm{ml}\right)$.

Contamination of the used tubes was avoided by heating the orifices of the tubes with a bunsen burner.

Inoculation of the root canals with the bacterial suspension

Parafilm was used to cover the outer surfaces of the eppendorf to form a closed chamber to avoid contamination of the bacterial suspension.

The root canals were completely filled with 250 microliter of bacterial suspension using one $\mathrm{ml}$ tuberculin syringe, a sterile k-file \#15 was used to carry the bacterial suspension to the full working length of the canals.

After that the samples were placed vertically inside a closed sterile plastic container with a flynn base immersed in water in the base of container to prevent dehydration of samples during incubation period.

Container containing samples was incubated aerobically at $37^{\circ} \mathrm{C}$ for 24 hours to confirm complete root canal infection with Enterococcus faecalis.

Initial culture sample was taken after 24 hours using sterile paper points to prove its contamination with the tested bacteria.

After collection of initial samples, paper points was inserted inside pre-labeled screw capped tubes containing $0.5 \mathrm{ml}$ sterile saline, and was vortexed to obtain a homogenous mix.

Then each sample was taken and spread on blood agar plate surface, and incubated aerobically at $37^{\circ} \mathrm{C}$ for one day.

Then obturation of prepared root canals was done by using lateral condensation technique. A modified sealer mixed with different nanoparticles according to the manufacturer's instructions and standardized gutta percha was applied into canals.

The teeth were kept in incubator at $37^{\circ} \mathrm{C}$ until use for the testing period to allow complete setting of the sealer.

According to the testing time, removal of gutta percha and sealer will be done using standard $\mathrm{H}$-file \# 35, then final irrigation was done using sterile saline as a wetting agent.

\section{Grouping}

The root canals were divided into three groups according to the type of tested sealer.

Group I: zinc oxide based sealer mixed with silver nanoparticles.

Group II: zinc oxide based sealer mixed with zinc oxide nanoparticles.

Group III: zinc oxide based sealer. (control group)

Each group was subdivided in to two sub groups each of ten teeth according to the timing of filling removal and culture sample.

Subgroup A: filling removal and culture sample were taken after one week.

Subgroup B: filling removal and culture sample were taken after three weeks.

According to the testing time, removal of gutta percha and sealer were done using standard $\mathrm{H}$-file \# 35, then final irrigation was done using sterile saline as a wetting agent.

Sampling technique and Microbiological processing

For each tooth, three bacterial samples were taken:

- S1: Initial (after incubation period of 24 hours and before biomechanical preparation).

- S2: Immediate (after one week of removal of tested sealer).

- S3: Final (after three weeks of removal of tested sealer). Each paper point was inserted as close as possible to the full working length and kept in place for ten seconds to collect the root canal contents and then transferred into the screw capped tube.

Using screw capped tube containing $0.5 \mathrm{ml}$ saline and paper point collected from each root canal was vortexed for ten seconds to obtain a homogenous suspension.

Calibrated disposable loops were used to obtain (10 microns) of bacterial suspension from each screw capped tube and streaking on the corresponding blood agar plates was performed. Using 5\% carbon dioxide candle jar the blood agar plates were incubated aerobically at $37^{\circ} \mathrm{C}$ for 24 hours.

After incubation period, the grown colony forming units (CFUs) were counted using a digital colony counter.

Data were recorded, tabulated and statistically analyzed using Friedman test to compare the differences between the three groups.

\section{RESULTS}

\section{Group (I)}

The colony forming units one week and three weeks after obturation showed a significant reduction in the number of bacterial count in comparison to initial samples (before obturation).( Fig.1)(Table.1)

In this group (zinc oxide sealer mixed with silver nanoparticles) the amount of inhibition rate between samples taken after incubation of the bacteria and after one week of obturation was $99.4 \%$. While the amount of inhibition rate found between samples after incubation of the bacteria and 3 weeks of obturation was $99.6 \%$. ( Fig.6) 
Table (1): Comparison between the percentage of colony forming units of Enterococcus faecalis 24 hours after inoculation versus one week and three weeks after obturation with zinc oxide sealer mixed to silver nanoparticles.

\begin{tabular}{|c|c|c|c|c||}
\hline \multirow{2}{*}{$\begin{array}{c}\text { CFU x 10 } \\
\text { oxide }+ \text { at Zinc } \\
\text { particles }\end{array}$} & \multicolumn{3}{|c|}{ Phase } & \multirow{2}{*}{$\boldsymbol{X}^{\mathbf{2}}$} \\
\cline { 2 - 4 } & $\begin{array}{c}\text { After } \\
\mathbf{2 4} \\
\text { hours }\end{array}$ & $\begin{array}{c}\text { After } \\
\mathbf{1} \\
\text { week }\end{array}$ & $\begin{array}{c}\text { After } \\
\mathbf{3} \\
\text { weeks }\end{array}$ & \\
\hline (P) \\
\hline Minimum & 40.0 & 0 & 0.0 & \\
Maximum & 2400.0 & 10 & 10.0 & 25.2 \\
Mean & 928.0 & 1.8 & 2.8 & $(0.00$ \\
SD & 729.1 & 3.1 & 2.8 & $1)^{*}$ \\
Median & $\mathbf{7 5 0 . 0}$ & $\mathbf{0 . 9}$ & $\mathbf{2 . 0}$ & \\
\hline
\end{tabular}

$\mathrm{X}^{2}$ : Friedman test

$* \mathrm{P}<0.05$ (significant)

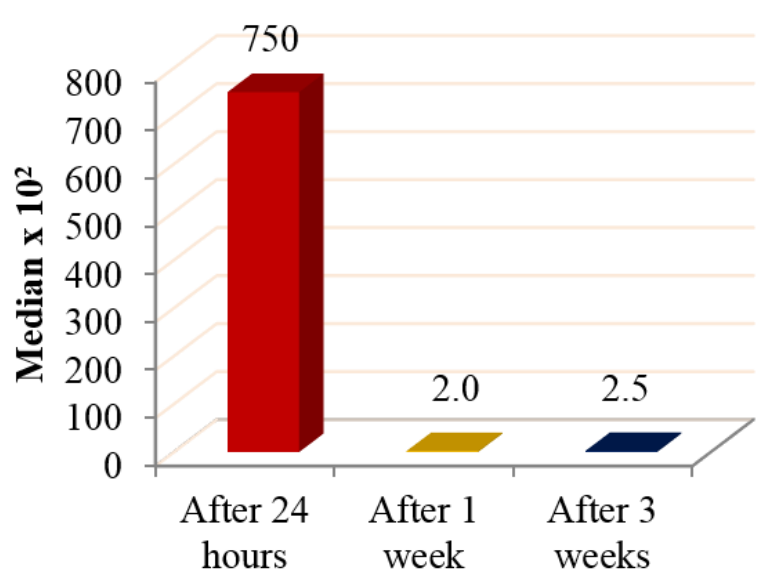

Phase

Figure (1): Comparison between the percentage of colony forming units of Enterococcus faecalis 24 hours after inoculation versus one week and three weeks after obturation with zinc oxide sealer mixed to silver nanoparticles.

\section{Group (II)}

The colony forming units one week and three weeks after obturation showed a significant reduction in the number of bacterial count in comparison to initial samples (before obturation).( Fig.2) (Table.2)

Table (2): Comparison between the percentage of colony forming units of Enterococcus faecalis 24 hours after inoculation versus one week and three weeks after obturation with zinc oxide sealer mixed to zinc oxide nanoparticles.

\begin{tabular}{|c|c|c|c|c||}
\hline \multirow{2}{*}{$\begin{array}{c}\text { CFU x 10 } \\
\text { oxide }+ \text { at Zinc } \\
\text { nano-particles }\end{array}$} & \multicolumn{3}{|c|}{ Phase } & \multirow{2}{*}{$\boldsymbol{X}^{2}$} \\
\cline { 2 - 4 } & $\begin{array}{c}\text { After } \\
\mathbf{2 4} \\
\text { hours }\end{array}$ & $\begin{array}{c}\text { After } \\
\mathbf{1} \\
\text { week }\end{array}$ & $\begin{array}{c}\text { After } \\
\mathbf{3} \\
\text { weeks }\end{array}$ & \\
\hline (P) \\
Minimum & 40.0 & 0 & 0.0 & \\
Maximum & 2000.0 & 8 & 7.0 & \\
Mean & 810.5 & 2.3 & 2.7 & 24.9 \\
SD & 692.6 & 2.3 & 2.4 & $(0.00$ \\
Median & $\mathbf{7 5 0 . 0}$ & $\mathbf{2}$ & $\mathbf{2 . 5}$ & \\
\hline
\end{tabular}

$\mathrm{X} 2$ : Friedman test

$* \mathrm{P}<0.05$ (significant)

In this group (zinc oxide sealer mixed with zinc oxide nanoparticles) the amount of inhibition rate between samples taken after incubation of the bacteria and after one week of obturation was $99.4 \%$. While the amount of inhibition rate found between samples after incubation of the bacteria and 3 weeks of obturation was $99.5 \%$. ( Fig.6)

\section{Group (III)}

The colony forming units one week and three weeks after obturation showed a significant reduction in the number of bacterial count in comparison to initial samples (before obturation).( Fig.3) (Table.3)

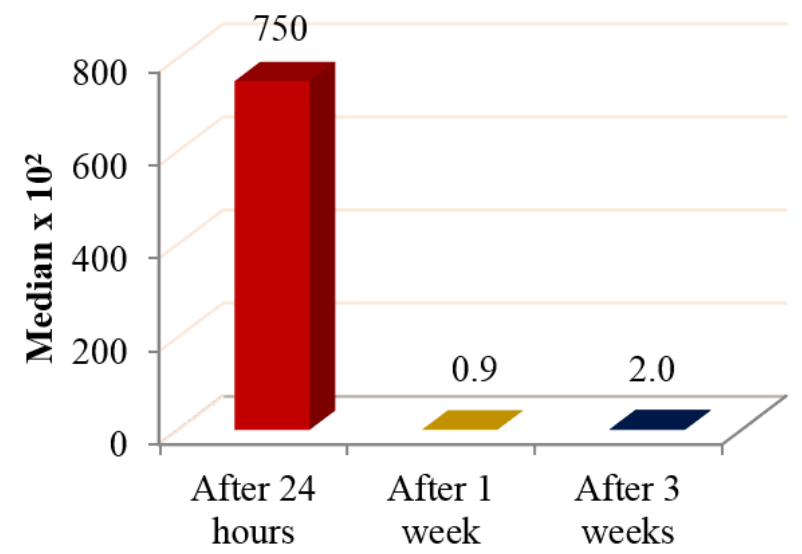

Phase

Figure (2): Comparison between the percentage of colony forming units of Enterococcus faecalis 24 hours after inoculation versus one week and three weeks after obturation with zinc oxide sealer mixed to zinc oxide nanoparticles.

Table (3): Comparison between the percentage of colony forming units of Enterococcus faecalis 24 hours after inoculation versus one week and three weeks after obturation with zinc oxide sealer.

\begin{tabular}{|c|c|c|c|c||}
\hline \multirow{2}{*}{$\begin{array}{c}\text { CFU x 10 } \\
\text { Zinc oxide }\end{array}$} & $\begin{array}{c}\text { After 24 } \\
\text { hours }\end{array}$ & $\begin{array}{c}\text { After 1 } \\
\text { week }\end{array}$ & $\begin{array}{c}\text { After 3 } \\
\text { weeks }\end{array}$ & \multirow{2}{*}{$\boldsymbol{X}^{\mathbf{2}}$ (P) } \\
\cline { 2 - 4 } & 100.0 & 0.0 & 10 & \\
Minimum & 5000.0 & 15.0 & 20 & \\
Maximum & 1770.0 & 7.2 & 16.2 & 29.5 \\
Mean & 1057.4 & 5.7 & 3.9 & $(0.001)$ \\
SD & & $\mathbf{1 7 . 5}$ & $\mathbf{1 8 . 5}$ & \\
Median & $\mathbf{1 7 0 0 . 0}$ & $\mathbf{1 7 . 5}$ & \\
\hline
\end{tabular}

X2: Friedman test

$* \mathrm{P}<0.05$ (significant)

In this group (zinc oxide sealer only) the amount of inhibition rate between samples taken after incubation of the bacteria and after one week of obturation was $98.9 \%$. While the amount of inhibition rate found between samples after incubation of the bacteria and 3 weeks of obturation was $98.6 \%$. ( Fig. 6 )

In comparison between the three tested groups, after three weeks from obturation silver nanoparticles had a superior antibacterial effect and there was a significant difference between the three tested groups, but after one week of obturation there was no significant difference between the three tested groups. ( Fig.4,5)

\section{DISCUSSION}

Endodontic sealers have an important role in the success of the endodontic treatment. So the use of an endodontic sealer with antibacterial properties may help to eliminate residual micro organisms, specially Enterococcus faecalis, that have survived after chemomechanical instrumentation and irrigation. 


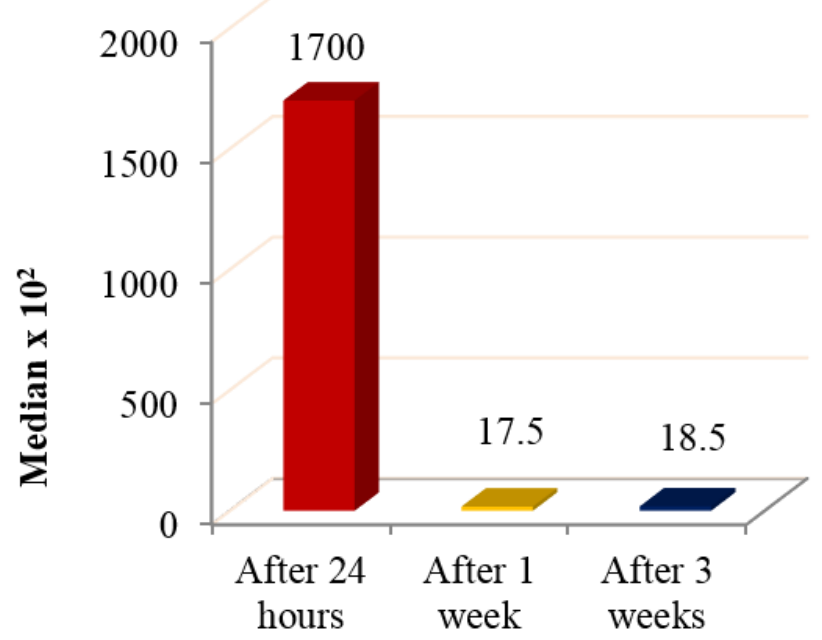

Figure (3): Comparison between the percentage of colony forming units of Enterococcus faecalis 24 hours after inoculation versus one week and three weeks after obturation with zinc oxide sealer.

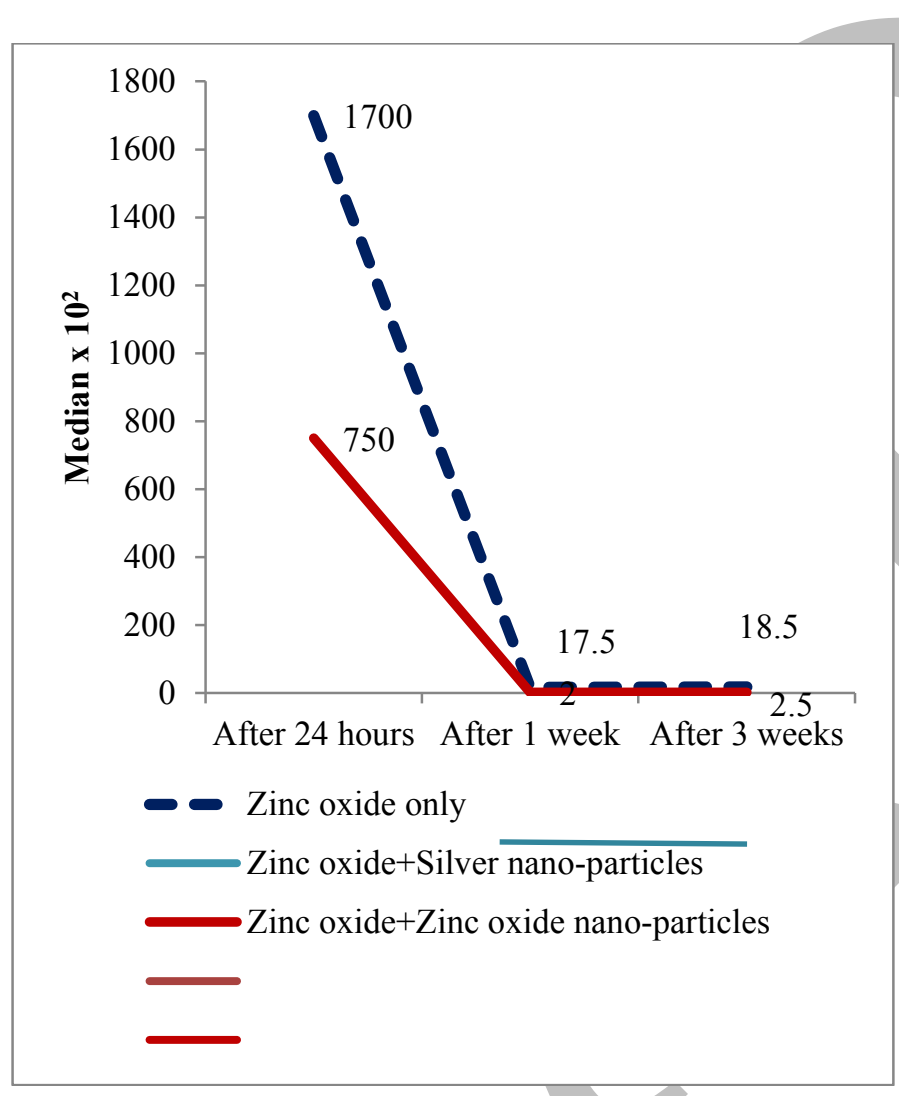

Figure (4): Comparison between the amount of bacterial count reduction one week and three weeks after obturaion in comparison to bacterial count 24 hours after inoculation of bacteria between the three tested groups.

The incorporation of antimicrobial components into root canal sealers may become an essential factor in preventing the regrowth of residual bacteria and control of bacterial reentry into the root canal space so the future use of nanoparticles appears bright because they can be used conjugated with other agents to further enhance their spectrum of use. In this study to determine the efficacy of nanoparticles as antibacterial agents against Enterococcus faecalis, they were compared with the traditional endodontic sealer used such as zinc oxide eugenol sealer.;

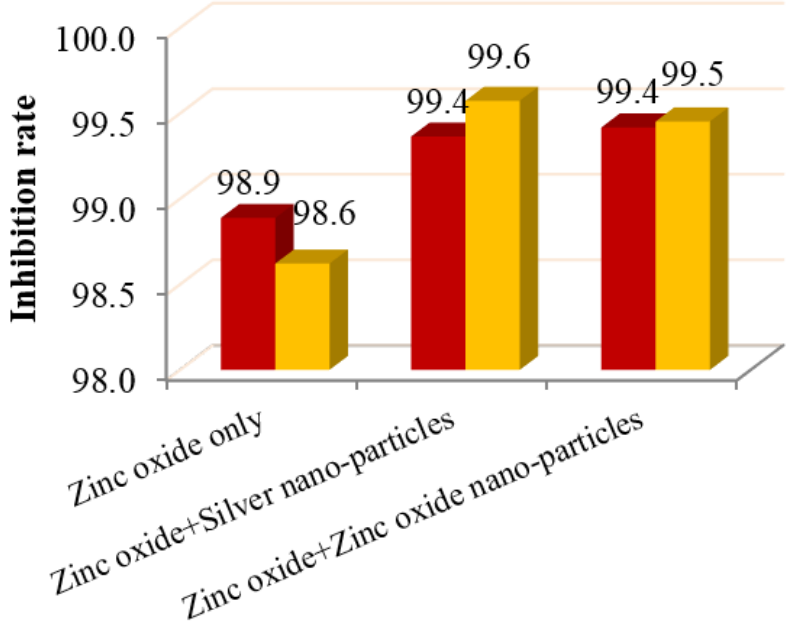

Figure (5): The amount of inhibition rate of the three tested groups against Enterococcus faecalis one week and three weeks after obturation.

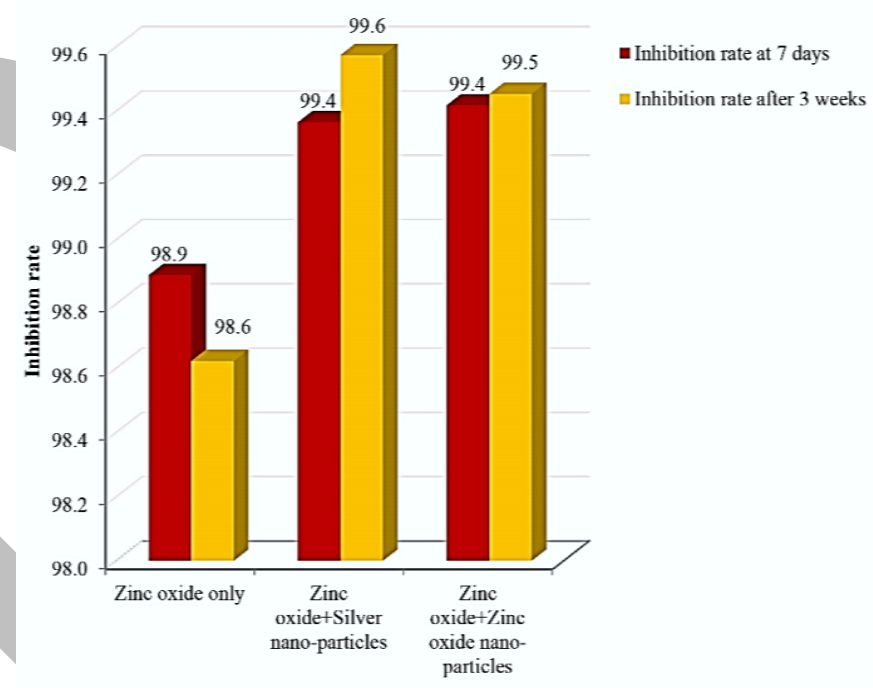

Based on the statistically significant differences among the three canal filling materials for permanent teeth evaluated in this study, it may be inferred that overall, sealer mixed with silver nanoparticles presented the highest antibacterial activity against Enterococcus faecalis followed by sealer mixed with zinc oxide nanoparticles and zinc oxide based sealer presented the lowest antibacterial activity among the tested materials.

When using Enterococcus faecalis as the tested organism, the present study showed that there was a significant reduction of colony forming units after seven days from obturation with conventional zinc oxide eugenol sealer (Endofill) $(\mathrm{p}<0.05)$. This was in agreement with Gomes et al. (2), Nelson-Filho et al (3), Ibrahem et al (4), Shakouie et al (5), Anumula et al (6), Kaiwar A et al (7) and Habeeb et al (8).

The antibacterial effect of Zinc oxide eugenol based sealer against Enterococcus faecalis could be attributed to the presence of eugenol as a main component. Eugenol is a phenolic compound that acts on microorganisms by denaturation whereby the protein becomes nonfunctional. It is also effective against mycotic cells and vegetative forms (9).

In 2004 Gomes et al (2) had shown that EndoFill and Endomethasone demonstrated the highest antimicrobial activity in their study. Furthermore, the antimicrobial activity 
of each sealer decreased with time. None of the tested sealers totally inhibited the microbial growth.

In 2014 Habeeb et al (8) found similar results to Gomes et al in 2004 (2) as they found that EndoFill Which is a zinc oxide eugenol based sealer had the maximum average zones of inhibition as compared to other tested sealers. EndoFill had favorable results among tested sealers and Enterococcus faecalis was the most resistant bacteria, but none of the materials totally inhibited microbial growth.

But in the final sample after three weeks, colony forming units were slightly increased. This is in agreement with Gomes et al. (2), Shakouie et al (5) and Anumula et al (6) who had shown the presence of increased Enterococcus faecalis, this could be attributed to that endodontic sealers have been shown to offer the greatest antimicrobial effects immediately after spatulation (11), following which there will be a gradual loss of antimicrobial effects over time (12) indicating that the antimicrobial activity of all sealers decreased with time.

When using silver nanoparticles with zinc oxide based sealer, the results showed a significant reduction of Enterococcus faecalis colony forming units after one week of obturation which remains nearly constant after three weeks from obturation. The antibacterial effect of silver nanoparticles could be related to the biologic effects of silver ion as they have a larger surface area for interaction. The main reasons for bacteriocidal properties of silver ions lies on the fact that positively charged nanoparticles electrostatically interact with the negatively charged bacterial cells resulting in altered cell permeability. These results were in accordance with Sofi et al (13), Chandrakanth et al (14), Wu et al (15), Daming et al (16), Krishnan et al (17) and Jafari et al (18) who found that silver nano particles had strong bactericidal effect.

Silver nanoparticles are attractive because they are nontoxic to the human body at low concentrations and have broad spectrum antibacterial actions (19). It is well known that smaller silver nanoparticles show stronger and better bacteriocidal effect than larger particles because they have a larger surface area for interaction (20).

The silver ions are highly reactive and they bind to proteins followed by structural changes in the bacterial cell wall and nuclear membrane, which leads to cell distortion and death. Silver ions have capacity to inhibit the bacterial replication, by binding and denaturing bacterial DNA $(21,22)$.

Another possible antibacterial mechanism of silver ions is the interaction with thiol groups in proteins, inducing the inactivation of bacterial proteins (23).

Our findings are consistent with Krishnan et al in 2015 (17) who stated that silver nanoparticles have potential bactericidal effects against Enterococcus faecalis at a concentration of five $\mathrm{mg} / \mathrm{ml}$.

Furthermore, the amount of nanoparticles added to each specimen was $2 \%(\mathrm{wt} / \mathrm{wt})$ in this study to be within the range used in previous studies as according to DaSilva et al (24), Tanomaru et al (25) and Barros et al (26) who studied the antibacterial properties after addition of nanoparticles with concentrations of $2 \%(\mathrm{wt} / \mathrm{wt})$.

When using zinc oxide nanoparticles as sealer, the results showed a significant reduction of Enterococcus faecalis colony forming units after one week of obturation which remain nearly constant after three weeks from obturation similar to reduction shown when using silver nanoparticles but smaller in number.
These results were in agreement with Kishen et al (27), Shrestha et al (28), Karvani et al (29), Arabi et al (30) and Tanomaru et al (25).

These findings could be attributed to the destructive effect of zinc oxide nanoparticles with the cells. Zinc oxide nanoparticles after its adherence to the surface of the cell membrane and penetration into bacteria, results in disturbance in its respiration as it interacts with enzymes of the respiration chains of bacteria leads to increased production of active oxygen such as hydrogen peroxide and inactivate their enzymes causing bacterial cell death (31-33).

Our findings are consistent with Karvani et al in 2011 (29) who had shown that zinc oxide nanoparticles are effective antibacterial agents both on Gram-positive and Gramnegative bacteria. The antibacterial effect for each concentration decreased gradually during 72 hours.

Furthermore a study done in 2014 by Tanomaru et al (25) found that zinc oxide nanoparticles showed antibacterial activity greater than for microparticles. Besides, it was demonstrated that the use of nanoparticulated zinc oxide increases the antimicrobial activity of some products, including biofilms of Staphylococcus aureus and Enterococcus faecalis.

Size of the nanoparticles is considered to be their unique characteristic, with a diameter of $100 \mathrm{~nm}$ or less (34), it is responsible for making them have a greater contact surface area and charge density than bulky powders. It is also responsible for its antibacterial role as it allows it to have a significantly greater degree of interaction and contact between the positively charged nanoparticles and the negatively charged bacterial cell surface (27).

This study used nanoparticles of silver and zinc oxide of an average size of $35 \mathrm{~nm}$, and $45 \mathrm{~nm}$, respectively. During the preparation of the nanoparticles a balance was maintained between preservation of the small size of nanoparticles to harvest its benefit yet at the same time ensuring its biocompatibility (24). Calcination was done at a temperature of $300^{\circ} \mathrm{C}$ for two hours for nanoparticles. The size of the nanoparticles was thus maintained at a size between $30-100 \mathrm{~nm}$ to avoid toxicity to the fibroblasts and macrophages for future invivo use.

The antibacterial activity of pure zinc oxide nanopowders decreases with increasing the calcination temperature. This can be related to the increase of the particle size of zinc oxide nanopowders at higher calcination temperature, since the effective surface area of zinc oxide nanopowders decreases with the particle size growth.

When comparing the obturation with silver nanoparticles and zinc oxide nanoparticles, the present study showed that there was a significant difference between both sealers in reduction of bacterial count after three weeks, but after one week from obturation there was more reduction but with no significant difference between them. These findings could be attributed to the fact that Silver nanoparticles take a period of time to contact the cell wall increasing its permeability, penetrate the bacterial cell and finally interact with the cellular structural elements leading to death of the bacteria.

In 2013 Shayani Rad et al (35) stated that the synthesized pure zinc oxide eugenol and zinc oxide eugenol mixed with silver nanopowders samples have better antibacterial properties, in comparison with zinc oxide eugenol conventional sealer. Also, the presence of silver nanoparticles has slightly enhanced the antibacterial effect 
of zinc oxide eugenol nanopowders, due to the antibacterial property of silver.

The results of this study showed that the synthesized pure zinc oxide nanoparticles and silver nanoparticles samples in this study clearly have better antibacterial properties, in comparison with zinc oxide eugenol conventional sealer because nanoparticles have larger surface area available for interactions which enhances the bactericidal effect than the large sized particles and hence they impart cytotoxicity to the microorganisms (36)

The antibacterial activity of pure zinc oxide nanopowders decreases with increasing the calcination temperature. This can be related to the increase of the particle size of zinc oxide nanopowders at higher calcination temperature, since the effective surface area of zinc oxide nanopowders decreases with the particle size growth.

In case of samples obtained after three weeks from obturation there was significant differences between the three tested groups this could be attributed to the presence of silver ions inside the mixture solution which had the ability and time to penetrate inside the dentinal tubules after seven days. Moreover, silver nanoparticles antibacterial activity exceeds that of their bulk equivalents. Nonetheless, high surface energy may compromise their efficacy due to their susceptibility to aggregate into large particles, which may result in the loss of their antibacterial activity.

Silver nanoparticles had better antibacterial activity than zinc oxide nanoparticles but the difference was not significant $(\mathrm{p}>0.05)$.

In this study bacteriological technique used was by culturing and counting the colony forming units, it is considered one of the most valid methods to detect viable bacteria. This was performed by Ehsani et al (10), Tanomaru et al (25), Arabi et al (30) and Jafari et al (18), it was selected to over-come the limitations of other techniques as agar diffusion test which is dependent on diffusion ability of the materials across the medium, physical properties of tested materials and the affinity of the material in the culture medium as performed by Ibraheem et al (4), Shakouie et al (5), Anumula et al (6) and Habeeb et al (8).

However, the main cause of the observed differences in the various studies can be due to the different methods for assessing of antimicrobial effects including agar diffusion and contact dilution. Also time factor is considered an important cause in the final results and differences observed ragrding other studies.

\section{CONCLUSIONS}

Under the conditions of this study it was concluded that:

1. Among the different types of nanoparticles used, sealer mixed with silver nanoparticles showed the best antibacterial effect, while when mixed with zinc oxide nanoparticles showed the least antibacterial effect.

2. All sealers exhibited bactericidal effect when freshly mixed, but the antibacterial activity of each sealer decreased with time.

3. Sealer mixed with different nanoparticles has a superior antibacterial effect than pure zinc oxide based sealer.

4. Incorporation of nanoparticles to sealers improves their antibacterial effect.

\section{Statement of conflict of interest}

The authors declare that they have no conflicts of interest.

\section{REFERENCES}

1. Leavis HL, Willems RJL, Top J, Spalburg E, Mascini EM, Fluit AC, et al. Epidemic and nonepidemic multidrug-resistant Enterococcus faecium. Emerg Infect Dis 2003; 9: 1108-15.

2. Gomes BP, Pedroso JA, Jacinto RC, Vianna ME, Ferraz $\mathrm{CC}$, Zaia AA, et al. In vitro evaluation of the antimicrobial activity of five root canal sealers. Braz Dent J 2004; 15: 30-5.

3. Queiroz AM, Nelson-Filho P, Silva LA, Assed S, Silva RA, Ito IY. Antibacterial activity of root canal filling materials for primary teeth: zinc oxide and eugenol cement, Calen paste thickened with zinc oxide, Sealapex and EndoREZ. Braz Dent J 2009; 20: 290-6.

4. Ibraheem AF, Salman HA. An in vitro evaluation of the antimicrobial activity of three root canal sealers. J Bagh College Dentistry 2009; 21: 28-31.

5. Shakouie S, Eskandarinezhad M, Shahi S, Mokhtari H, FroughReihani M, Soroush M, et al. Antimicrobial efficacy of AH-Plus, adseal and endofill against Enterococcus faecalis-An in vitro study. Afr J Microbiol Res 2012; 6: 991-4.

6. Anumula L, Kumar S, Kumar VS, Sekhar C, Krishna M, Pathapati RM, et al. An Assessment of Antibacterial Activity of Four Endodontic Sealers on Enterococcus faecalis by a Direct Contact Test: An In Vitro Study. ISRN Dent 2012; 2012: 989781.

7. Kaiwar A, Nadig G, Hegde J, Lekha S. Assessment of Antimicrobial Activity of Endodontic Sealers on Enterococcus faecalis: An in vitro Study. World J Dent 2012; 3: 26-31.

8. Habeeb MA. Analysis of antimicrobial activity of root canal sealers against endodontic pathogens using agar diffusion test. J Bagh College Dentistry 2014; 26: 27-34.

9. Kaplan AE, Picca M, Gonzalez MI, Macchi RL, Molgatini SL. Antimicrobial effect of six endodontic sealers: an in vitro evaluation. Dental Traumatology 1999; 15: 42-5.

10. Ehsani M, Adibi A, Moosavi E, Dehghani A, Khafri S, Adibi E. Antimicrobial activity of three different endodontic sealers on the enterococcus faecalis and lactobacillus (in vitro). Caspian J Dent Res 2013; 2: 814.

11. Orstavik D. Antibacterial properties of endodontic materials. Int Endod J 1988; 21: 161-9.

12. Weiss EI, Shalhav M, Fuss Z. Assessment of antibacterial activity of endodontic sealers by a direct contact test. Endod Dent Traumatol 1996; 12: 179-84.

13. Sofi W, Gowri M, Shruthilaya M, Rayala S, Venkatraman G. Silver nanoparticles as an antibacterial agent for endodontic infections. Bio Med Central Ltd 2012; 12: 60-6.

14. Chandrakanth RK, Ashajyothi C, Oli AK, Prabhurajeshwar C. Potential bactericidal effect of silver nanoparticles synthesised from enterococcus species. Orient J Chem 2014; 30: 1253-62.

15. Wu D, Fan W, Kishen A, Gutmann JL, Fan B. Evaluation of the Antibacterial Efficacy of Silver Nanoparticles against Enterococcus faecalis Biofilm. J Endod 2014; 40: 285-90. 
16. Daming Wu, Fan W, Kishen A, Gutmann JL, Fan B. Evaluation of the antibacterial efficacy of silver nanoparticles against Enterococcus faecalis Biofilm. J Endod 2014; 40: 285-90.

17. Krishnan R, Arumugam V, Vasaviah SK. The MIC and MBC of Silver Nanoparticles against Enterococcus faecalis - A Facultative Anaerobe. J Nanomed Nanotechnol 2015; 6: 285.

18. Jonaidi-Jafari N, Izadi M, Javidi P. The effects of silver nanoparticles on antimicrobial activity of ProRoot mineral trioxide aggregate (MTA) and calcium enriched mixture (CEM). J Clin Exp Dent 2016; 8: e22-6.

19. Rai M, Yadav A, Gade A. Silver nanoparticles as a new generation of antimicrobials. Biotechnol Adv 2009; 27: 76-83.

20. Gomes-Filho JE, Silva FO, Watanabe S, Cintra LT, Tendoro KV, Dalto LG, et al. Tissue reaction to silver nanoparticles dispersion as an alternative irrigating solution. J Endod 2010; 36: 1698-702.

21. Landsdown AB. Silver. I: Its antibacterial properties and mechanism of action. J Wound Care 2002; 11: 12530 .

22. Castellano JJ, Shafii SM, Ko F, Donate G, Wright TE, Mannari RJ, et al. Comparative evaluation of silvercontaining antimicrobial dressings and drugs. Int Wound J 2007; 4: 114-22.

23. Feng QL, Wu J, Chen GQ, Cui FZ, Kim TN, Kim JO. A mechanistic study of the antibacterial effect of silver ions on Escherichia coli and Staphylococcus aureus. J Biomed Mater Res 2000; 52: 662-8.

24. DaSilva Luis, Finer Yoav, Perez Davidi M, Weiss EI, Beyth. Biofilm formation within the interface of bovine root dentin treated with conjugated chitosan and sealer containing chitosan nanoparticles. J Endod 2013; 39: 249-53.

25. Guerreiro-Tanomaru JM, Trindade-Junior A, Costa BC, da Silva GF, Drullis Cifali L, Basso Bernardi MI, et al. Effect of zirconium oxide and zinc oxide nanoparticles on physicochemical properties and antibiofilm activity of a calcium silicate-based material. ScientificWorldJournal. 2014; 2014: 975213.

26. Barros J, Silva MG, Rodrigues MA, Alves FRF, Lopes MA, Pina-Vaz I, et al. Antibacterial, physicochemical and mechanical properties of endodontic sealers containing quaternary ammonium polyethylenimine nanoparticles. Int Endod J 2014; 47: 725-34.

27. Kishen A, Shi Z, Shrestha A, Neoh KG. An investigation on the antibacterial and antibiofilm efficacy of cationic nanoparticulates for root canal disinfection. J Endod 2008; 34: 1515-20.

28. Shrestha A, Zhilong S, Gee NK, Kishen A. Nanoparticulates for Antibiofilm Treatment and Effect of Aging on Its Antibacterial Activity. J Endod 2010; 36: 1030-5.

29. Emami-Karvani Z, Chehrazi P. Antibacterial activity of $\mathrm{ZnO}$ nanoparticle on grampositive and gram-negative bacteria. Afr J Microbiol Res 2011; 5: 1368-73.

30. Arabi F, Imandar $M$, Negahdary $M$, Imandar $M$, Noughabi MT, Akbari-dastjerdi H, et al. Investigation anti-bacterial effect of zinc oxide nanoparticles upon

31. life of Listeria monocytogenes. Ann Biol Res 2012; 3 : 3679-85.
32. Darryl NW, Sheryl HE, Tracey RPH. Evaluation of the microbial growth response to inorganic nanoparticles. J Nanobiotechnol 2006; 4: 1477-80

33. Huang Z, Zheng X, Yan D, Yin G, Liao X, Kang Y, et al. Toxicological effect of $\mathrm{ZnO}$ nanoparticles based on bacteria. Langmuir 2008; 24: 4140-4.

34. Sierra J, Ruiz F, Pena D, Gutierrez FM. The Antimicrobial sensitivity of Streptococcus mutants to nanoparticles of silver, zinc oxide and Gold. Int J Nanoparticles 2008; 2: 402-15.

35. Zhang G, Niu A, Peng S, Jiang M, Tu Y, Li M, et al. Formation of novel polymeric nanoparticles. Acc Chem Res 2001; 34: 249-56.

36. Rad MS, Kompany A, Zak AK, Javidi M, Mortazavi SM. Microleakage and antibacterial properties of $\mathrm{ZnO}$ and $\mathrm{ZnO}: \mathrm{Ag}$ nanopowders prepared via a sol-gel method for endodontic sealer application. J Nanopart Res 2013; 15: 1925.

37. Doty C, Tshikhudo R, Brust M, Fernig D. Extremely stable water soluble $\mathrm{Ag}$ nanoparticles. Chem. Mater 2005; 17: 4630-5.

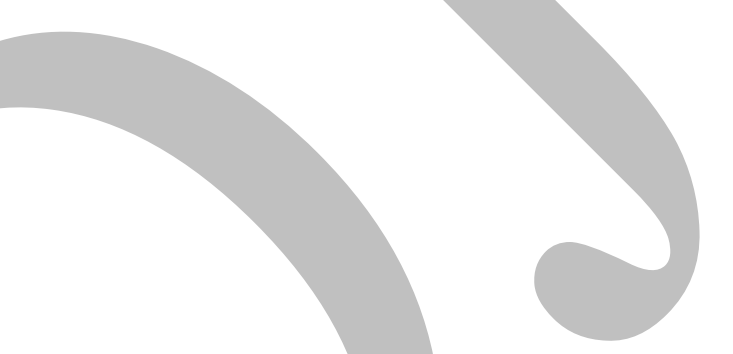

